\title{
Effects of Rural Livelihood Activities on Income Inequality and Poverty Reduction in the Guinean Coastal Area
}

\author{
Boubacar Siddighi Balde ${ }^{1}$, Hajime Kobayashi ${ }^{2}$, Akira Ishida ${ }^{3}$, Makoto Nohmi ${ }^{2}$, Mohamed Esham ${ }^{4}$, \\ Ichizen Matsumura $^{2} \&$ Emmanuel Tolno ${ }^{1}$ \\ ${ }^{1}$ The United Graduate School of Agricultural Sciences, Tottori University, Tottori, Japan \\ ${ }^{2}$ Faculty of Agriculture, Tottori University, Tottori, Japan \\ ${ }^{3}$ Department of Regional Development, Shimane University, Shimane, Japan \\ ${ }^{4}$ Faculty of Agricultural Sciences, Sabaragamuwa University of Sri Lanka, Belihuloya, Sri Lanka \\ Correspondence: Boubacar Siddighi Balde, The United Graduate School of Agricultural Sciences, Tottori \\ University, Tottori, Japan. Tel: 81-80-4264-8171. E-mail: siddighilonsin@hotmail.com
}

Received: January 14, 2014 Accepted: March 25, 2014 Online Published: May 15, 2014

doi:10.5539/jas.v6n6p113 URL: http://dx.doi.org/10.5539/jas.v6n6p113

\begin{abstract}
This paper investigated the influence of portfolio of livelihood activities on income inequality and poverty reduction in the Guinean coastal area. The study used primary data collected through a survey of salt producers, mangrove rice farmers and wood loggers along the Guinean coast in Koba. The survey used a questionnaire to collect data on peasants' characteristics and their income sources. To examine the effects of livelihood activities on income inequality and poverty reduction, Gini decomposition analysis and poverty decomposition techniques such as Foster-Greer-Thorbecke (FGT) index were used. The results revealed that salt production and vegetable production give rise to income inequality. Therefore, by enhancing the share of income from mangrove rice production, wood extraction, non-farm income, livestock, seasonal crop production, lowland rice production, remittance and perennial crop production has the potentials to reduce income disparity among the peasants. Poverty measures also revealed that the degree of poverty reduction largely depends on the extent to which livelihood activities of the peasants can be diversified. The government could remedy the income inequality arising from salt production and reduce poverty by providing machineries and tools to poorer farmers to ensure their participation in salt production. Further, this research also highlights the need to put more emphasis on mangrove rice production due to its high potential to reduce income inequality in the region.
\end{abstract}

Keywords: livelihood activities, income inequality, poverty reduction, Guinean coast, Koba

\section{Introduction}

In Guinea, coastal lands play a key role in national food security in terms of agricultural production focused on rice, salt production, etc., and over one-third of the country's population who live in coastal lands. Income inequality is one of the major contributing factors of poverty and food security in developing countries, while leaving a substantial proportion of their populations to languish in poverty and suffer from problems associated with chronic malnutrition (Peters \& Shapouri, 1997). Inequality also matters to the pace of poverty reduction that is achieved at any given rate of growth (Ravallion, 2001). Since 2003; Guinea has experienced a serious economic crisis, which has exacerbated the poverty. Poverty was decreased significantly between 1994/95 and 2002/03, falling by more than 13 percent. However, the incidence of poverty at the national level has gone up from $53 \%$ in 2007 to $55.2 \%$ in 2012 (INS, 2012). In addition, the number of poor increased very significantly from 4 million to over 6.2 million over the past two decades, due to the aggravation of poverty and high population growth associated with high fertility.

Demographically, Guinea is characterized by rapid population growth and marked by strong regional disparities. In fact, total population grew from 9.7 million inhabitants in 2007 to about 11.3 million in 2012, at an average annual growth rate of $3.1 \%$ (equivalent to doubling every 22.5 years), and is made up mostly of women (52\%). An age breakdown shows a high proportion of youth. In fact, $22 \%$ of women and $23 \%$ of men are aged $15-19$ years. About $18 \%$ of women and $17 \%$ of men belong to the $20-24$ age groups. This demographic growth rate remains worrisome and prejudicial to the economic development of the country, as it leads to strong social 
demand (specifically for education, health care, housing, employment and transport) to which social policy must respond. The Synthetic Fertility Index (ISF) remains high, 5.1 children per woman, according to Demography and Health Study [EDS4-2012, reported by IMF, (2013)]. This Total Fertility Rate (TFR) level is putting more and more pressure on social services and employment. It can be explained by, among other things, the precarious socioeconomic status of women, especially by their low level of education, generally low standard of living in the household, weak economic power and lack of knowledge about their own reproductive system.

The development of indicators of poverty and some social indicators show that Guinea will not reach the Millennium Development Goals by 2015 (INS, 2012). The current economic situation is very different from the one which prevailed between 1994 and 2002, a period during which the country's economy has experienced strong growth in GDP per capita. A comparative analysis of surveys conducted in 1994/95 and 2002/03 showed a decline in poverty from $62.6 \%$ in 1994 to $49.1 \%$ in 2002 . Nowadays, there is an ongoing and increasing interest in measuring and understanding the level, causes and development of income inequality (Heshmati, 2004).

An improved understanding of the sources of income and income distribution provides instructive insights into poverty and helps policy makers in the developing world to formulate new strategies for its mitigation. In the perspective of inclusive growth strategies, it is important to undertake analysis of the dynamics of poverty, analysis of inequality in income distribution and the effects of these changes on dynamics of poverty. Hence, the present study aims to investigate the effect of livelihood activities on the income inequality and poverty in the coast of Guinea.

\subsection{Literature Review on Poverty and Inequality}

Poverty and inequality depends on the household earning capacities. Recently, there has been a growing recognition that rural households receive their income from a diverse portfolio of activities (Castagnini et al., 2004). Income levels and its distribution had attracted many researchers. The focus in these researches is on finding the welfare levels of households and to compare their situation. Thus, poverty and inequality are the keywords for development researchers. Poverty exists in a given society when one or more persons do not enjoy a level of material well-being deemed to constitute a reasonable minimum by the standard of that society (Sen, 1999). Inequality is closely related to the definition and conceptualization of poverty. The close link between poverty and inequality is partly supported by the fact that the latter has been defined or measured in the context of the former (Sen, 1976; Foster et al., 1984). In practice, the association between the two developmental issues has moved in varied directions in different countries, suggesting an intriguing relationship (Bourguignon, 2004). More interesting to this discourse is the characterization of the two concepts: that is, the degree of aggregation (unit of analysis) and whether what is being considered for measurement (income, consumption, wealth, etc.) is the same or varies between poverty and inequality. While inequality deals with the entire distribution, poverty either reflects the proportion below the poverty line (absolute poverty) or is measured based on the characteristics of other units in the sample (relative poverty). The variations in the characterization of both poverty and inequality partially account for the depth of the discussion that is taking place on these developmental issues. In sum, the conceptual difference between poverty and inequality is nuance.

Also, the discourse on poverty and inequality has deepened in recent times based on the outcomes of empirical studies that seek to evaluate the ability of the developing countries to achieve the MDG1 target of halving poverty by 2015. Imai et al. (2010) assert that while globally the goal of halving poverty is on course, many individual countries and regions are struggling to achieve this goal. Also, Fosu (2011) argues that even if all countries grow at a desired rate (such as the purported seven per cent growth rate) necessary for achieving MDG1, this criterion will not be sufficient for all developing countries, given their idiosyncratic factors such as inequality. On the nature of inequality, one dimension currently being explored in the literature is spatial disparity. This is because there is a growing sense across much of the developing world and other transitional economies that spatial and regional inequality of income, consumption, economic activities and other social indicators is on the increase (Kanbur \& Venables, 2003; McKay \& Aryeetey, 2007; World Bank, 2009). More importantly, the trend towards increased regional inequalities comes within the context of positive economic growth in several parts of the developing world in recent times, especially in previously poorly performing regions, such as sub-Saharan Africa (Aryeetey et al., 2009).

Both poverty and inequality have increasingly become multi-disciplinary, given their multi-dimensionality and dynamism. For instance, economists have explored the growth-poverty nexus based on the role of inequality (Fosu, 2011; Bourguignon, 2004; Ravallion, 1997), while sociologists, among other theories, have argued that poverty and inequality are outcomes of social categorization and identity that self-perpetuate themselves within a 
society (Mosse, 2010). Another twist to this discourse is the relationship between poverty and inequality - that is, whether they are dependent or independent, or whether they both mutually cause the occurrence of other outcomes. Barber (2008) suggests that the relationship between poverty and inequality is either pragmatic, that is, inequality exacerbates poverty, or moral, that is, inequality is a form of poverty.

\subsection{Poverty and Inequality in Guinea}

Poverty is a multidimensional phenomenon characterized by weak consumption of goods, malnutrition and bad living conditions, as well as by difficult access to public and basic social services (education, health care, safe drinking water and sanitation, etc.). It is also the result of loss of autonomy and of exclusion. It should be perceived not only as a lack of material goods and possibilities, such as, for example, employment and property, but also as the absence of physical and social assets, such as healthcare, corporeal sovereignty, shelter from fear and violence, a sense of belonging, cultural identity, ability to have political influence and the possibility of living with respect and dignity.

The poverty threshold is fixed at 3217305 Guinean Franc (GNF) per capita and per year at 2012 prices, or nearly 8815 GNF per capita, per day. This threshold was determined on the basis of a 2002/03 survey, updated in 2007 and 2012 to reflect inflation. According to results of the two surveys, the incidence of poverty at the national level has gone from 53\% in 2007 to $55.2 \%$ in 2012, an increase of 2.2 percentage points (Table 1). The trend shows that the number of individuals living below the poverty line increased from 5.1 million in 2007 to 6.2 million in 2012. This increase in the number of poor poses a real challenge in terms of access to basic social services, employment and land development planning. On the other hand, the extent and severity of poverty have worsened between the two periods, moving, respectively, from $17.6 \%$ to $18.4 \%$ and from $8.2 \%$ to $8.4 \%$. This reflects a widening of the gap between average spending by the poor and the poverty threshold.

Furthermore, the extent and severity of poverty are greater in rural areas than in urban areas, along with the incidence of poverty itself. Gini inequity coefficients calculated with data from the 2007 and 2012 ELEP (Small-Scale Surveys for the Evaluation of Poverty) conducted by the National Institute of Statistics (INS) reveal that inequity of income distribution increased over the period. In fact, the Gini index increased from 0.312 to 0.317 (Table 1). This increase is most strongly felt in urban areas (0.290 in 2007 to 0.315 in 2012). In rural areas, by contrast, there was a slight decline, with the Gini index moving from 0.295 in 2007 to 0.290 in 2012.

Table 1. Trends of poverty and inequality

\begin{tabular}{llllllll}
\hline \multirow{2}{*}{ Indicators } & \multicolumn{3}{c}{$\mathbf{2 0 0 7}$} & & \multicolumn{3}{c}{$\mathbf{2 0 1 2}$} \\
\cline { 2 - 3 } Incidence & Urban & Rural & Total & & Urban & Rural & Total \\
Extent & 30.5 & 63.0 & 53.0 & & 35.4 & 64.7 & 55.2 \\
Severity & 7.7 & 22.0 & 17.6 & & 9.6 & 22.6 & 18.4 \\
\% Population & 3.0 & 10.5 & 8.2 & & 3.8 & 10.5 & 8.4 \\
\% Poor & 17.7 & 82.3 & 100 & & 20.8 & 71.2 & 100 \\
Number of poor & 907519 & 4224191 & 5131710 & & 1285039 & 4927703 & 6212742 \\
Gini & 0.290 & 0.295 & 0.312 & & 0.315 & 0.290 & 0.317 \\
\hline
\end{tabular}

Source: INS, (2012); IMF, (2013). 


\section{Methodology}

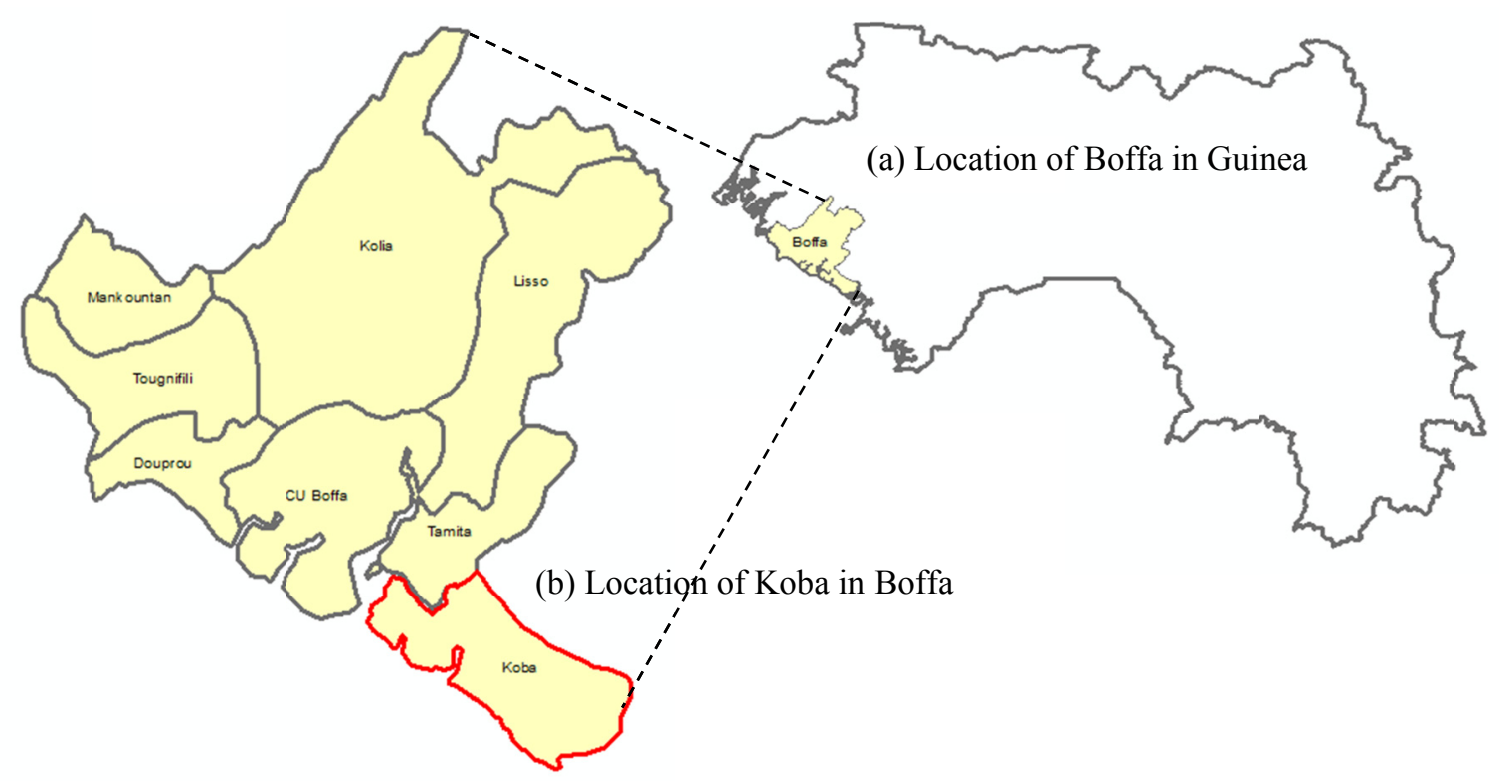

Figure 1. Location of the study area

\subsection{Study Area}

Koba sub-prefecture (Figure 1b) is one of the eight sub-prefectures (Tamita, Lisso, CU Boffa [urban commune of Boffa], Douprou, Kolia, Tougnifili and Mankountan) of Boffa prefecture (Figure 1a). It is located hundred kilometers away from the Boffa prefecture, covering an area of $1026 \mathrm{~km}^{2}$ with a total population of 52720 inhabitants of which 27304 are females. Koba is bordered to the North by Tanene sub-prefecture of Dubreka prefecture, to the West by Mara Island in the urban commune of Boffa and to the South-East by the Atlantic Ocean. Koba is the main area in Guinea in terms of mangrove rice and salt production. The study area is home for the agronomic research center of Koba (CRAK) which specializes in the experimentation of mangrove and freshwater rice varieties. This area has many facilities and infrastructures compared to all other sub-prefectures throughout Guinea.

\subsection{Data Collection}

This study is based on primary cross sectional data collected from four districts (Balessourou, Taboria, Makinsi and Bentya) located in Koba sub-prefecture in the Boffa prefecture. These are the major districts in which economic activities such as salt production, wood extraction; traditional and improved mangrove rice production are undertaken. Districts were selected based on information obtained from key informants. These districts were purposively selected in order to cover the main livelihood activities (previously mentioned above) in the study site. This purposive sampling was based on advice from experts combined with researchers' judgment and rapid exploratory studies in the study area. A Field survey was conducted from March to April 2013. A structured questionnaire was used to collect data on characteristics of peasants and their income sources from different economic activities in which they are involved. The questionnaire was administered to 220 respondents mainly belonging to five different groups: 60 traditional salt producers, including mixed salt (Guinean saline) producers; 40 salt marsh producers; 20 wood loggers; 50 traditional mangrove rice producers and 50 improved mangrove rice producers. It is important to indicate that respondents in each group were randomly selected. Personal interviews and field observations were undertaken to compliment and triangulate the answers provided by the respondents to the questionnaire.

\subsection{Income Sources From a Portfolio of Livelihood Activities in the Guinean Coastal Zone}

The livelihood portfolio is bundle of activities households engage in to generate livelihood and achieve a certain level of livelihood security (Rudie, 1995), while diversification of income sources has been put forward as one of the strategies households employ to minimize household income variability and ensure a minimum level of income (Alderman \& Paxson, 1992). In this paper, the total income of interviewed peasants is mainly divided 
into the following categories: 1) Agricultural income is sub-divided into mangrove rice farming, lowland rice production, vegetable production, seasonal and perennial crop production. 2) Salt production, 3) Wood extraction, 4) Livestock, 5) Non-farm income and 6) Remittance. Following Azam \& Shariff (2011), each component of household income listed here is normalized by household size to get per capita, and analysis is performed on the per capita of income from different categories of income sources. Referring to Reardon \& Taylor (1996), disposable income sources are in net terms.

\subsubsection{Agricultural Income}

2.3.1.1 Mangrove rice production income: imputed value of the total production of mangrove rice varieties (local and improved) including household consumption, quantity reserved for future seed, gift, etc., plus gross sales less input costs. Except the mangrove rice production in Balessourou (Sub-section 2.3.2), it was also cultivated in Bentya and Makinsi districts. The traditional mangrove rice cultivation was practiced in Makinsi and the only improved area was the large abandoned basins of shrimp farming. The improved mangrove rice farming was practiced in Bentya except the one mentioned in Balessourou. The mangrove rice farming involves the use of cleared mangrove forest land for rice production (Balde et al., 2013a). It represents rice cultivation in the plains of the mangrove forests. This farming system, practiced in coastal areas where the population is relatively dense, is one of the oldest forms of rice culture in West Africa.

2.3.1.2 Lowland rice production: the income from lowland rice production constitutes also the imputed total production value of lowland rice produced by farmers plus gross sales less input costs. In the whole Guinea, the lowland rice accounts for $10 \%$ of land under rice. Forest Guinea region accounts for the largest stretch of lowland compared to the country's other natural regions (Maritime/Lower Guinea, Middle Guinea and Upper Guinea).

2.3.1.3 Vegetable production income: here the total income constitutes the imputed value of total production of the following crops: pepper, eggplant, okra and tomato plus gross sales minus input costs.

2.3.1.4 Annual or seasonal crop production income: value of seasonal crop production for sale, own consumption and other uses. The seasonal crops refer to the cassava, peanut, sweet potato and fonio (Note 1) (local cereal, it is also cultivated in other West African countries like Senegal).

2.3.1.5 Perennial crop production income: value of production for sale, consumption and other orientation of uses. Perennial crops include banana, kola and palm trees belonging to the household.

2.3.2 Salt production income: imputed value of salt production for sale and own consumption from the traditional and improved techniques of salt minus input costs. For further details about these techniques of salt production in the Guinean coastal area refer to (Balde et al., 2013b). Salt production was practiced along the coastline of Balessourou including Pompage sector in Koba. This area was separated from the improved area of mangrove rice farming by a large embankment which also serves as a route connecting Balessourou to Kindiady, another fishing port and mangrove wood market. This proximity of salt production area and improved zone of mangrove rice farming could explain the involvement of Salt Marsh (SM) producers in both activities. In addition, saving time due to the adoption of improved salt production is another reason. Balde et al. (2013b) reported that the saving time due to improved salt production enable SM producers to earn a profit from the mangrove rice production.

2.3.3 Wood extraction: value of the pole (laths) and chopped-off wood for sale. The length of poles varies between 6 to $7 \mathrm{~m}$; while the chopped-off wood between 1.10 to $1.20 \mathrm{~m}$. Surveyed wood loggers operate at two sites, Keregnon and Kito (Main Island) accessible only by canoes from Koba, the main inland. These wood loggers live in Kito, but mangrove woods are marketed in Taboria, principal port in Koba. Their permanent contact, proximity to the mangrove forest and isolation from cultivated mangrove areas indicated the reason that wood extraction remains as their main income source as indicated in Table 3. Wood loggers were found practicing livestock, non-farm activities and receiving remittance.

2.3.4 Livestock: it represents the net sales plus the imputed value of home consumption. This livestock ranges from poultry (domesticated birds such as chickens, turkeys and ducks), cattle, sheep and goat.

2.3.5 Non-farm income: this indicates the income from regular and casual employment of the household members. In the other words, this is the local income from sources other than cropping, livestock husbandry, etc., including commerce, local wage employment, services and so on.

2.3.6 Remittance: this represents remittances from absent family members and from relatives living in other cities in Guinea or abroad. 


\subsection{Empirical Methods}

Data were analyzed by selecting the common methods for the determination of inequality and poverty indices. The Gini decomposition analysis is considered to be the best measure of inequality and is widely used in economic research (Shorrocks, 1982). The ability to decompose measures of inequality from contributing sources is a desirable property for studies of economic inequality (Okamoto, 2009). Given its advantages and usefulness, the Gini decomposition analysis is employed to determine the income inequalities of livelihood activities. To estimate the effects of livelihood activities on poverty reduction, the well-known poverty measure, the Foster-Greer-Thorbecke class (including the headcount ratio and the poverty gap ratio) was computed. The poverty measurement can also be computed by using the following methods: the income gap ratio and the aggregate poverty gap, the Sen, Takayama, Thon and Watts indices, and measures from the Clark-Hemming-Ulph class (Stata Technical Bulletin, 1999 (STB-48)).

\subsubsection{Gini Decomposition Analysis}

The measures of income inequality can be divided into positive and normative measures. The positive measures are derived from statistical concepts and make no explicit use of any concept of social welfare. These include the Gini coefficient, Lorenz curve, Theil measure, relative mean deviation and the coefficient of variation. In contrast, the normative measures, the Dalton measure and Atkinson index, links and integrates the measure of inequality with social welfare and rely on value judgments and a properly defined function. According to Shorrocks (1982), the Gini coefficient is considered to be the best measure of inequality and is widely used in economic research.

The Gini coefficient or index (Gini, 1912; Alina, 2008) is perhaps one of the most used indicators of social and economic condition. This measure is understood by many economists and has been applied in numerous numerical studies and policy research. The Gini index can be used to measure the dispersion of a distribution of income, or consumption, or wealth or any kind of distribution. In this study, the Gini coefficient was used to measure the degree of inequality of income generated by farmers involved in various activities in the coastal area of Guinea. The Gini coefficient is a number or index varying between zero and one; zero signifies perfect equality, and one perfect inequality. The United Nations Development Programme (1992) indicated that Gini coefficients for countries with high inequality typically lie between 0.5 and 0.7 . Following Shorrocks (1982), Lerman \& Yitzhaki (1985), the Gini coefficient for total income inequality, G, can be represented as:

$$
\mathrm{G}=\sum_{k=1}^{K} R_{k} G_{k} S_{k}
$$

Where $S_{k}$ represents the share of component $k$ in total income, $G_{k}$ is the source Gini corresponding to the distribution of income from source $\mathrm{k}$, and $\mathrm{R}_{\mathrm{k}}$ is the Gini correlation of income from source $\mathrm{k}$ with the distribution of total income. According to Stark, Taylor and Yitzharki (1986), the relation among these three terms has a clear and intuitive interpretation; the influence of any income component upon total income inequality depends on: (a) how important the income source is with respect to total income $\left(\mathrm{S}_{\mathrm{k}}\right)$; (b) how equally or unequally distributed the income source is $\left(\mathrm{G}_{\mathrm{k}}\right)$; (c) how the income source and the distribution of total income are correlated $\left(\mathrm{R}_{\mathrm{k}}\right)$. If an income source represents a large share of total income, it may potentially have a large impact on inequality. However, if income is equally distributed $\left(\mathrm{G}_{\mathrm{k}}=0\right)$, it cannot influence inequality, even if its magnitude is large. On the other hand, if this income source is large and unequally distributed $\left(S_{k}\right.$ and $G_{k}$ are large), it may either increase or decrease inequality, depending on which households, at which points in the income distribution, earn it. If the income source is unequally distributed and flows disproportionately toward those at the top of the income distribution ( $\mathrm{R}_{\mathrm{k}}$ is positive and large), its contribution to inequality will be positive. However, if it is unequally distributed, but targets poor households, the income source may have an equalizing effect on the income distribution.

\subsubsection{FGT (Foster-Greer-Thorbecke) Index}

In order to investigate the effect of livelihood activities on poverty reduction in the coastal area, this study used the Foster-Greere-Thorbecke (FGT) poverty index (1984). The FGT poverty measure is defined as:

$$
P_{\alpha}=\frac{1}{n} \sum_{i=1}^{m}\left(\frac{z-y_{i}}{z}\right)^{\alpha}
$$

Where $n$ is the sample size, $i$ subscripts the household or individual, $m$ is the total number of households living under the poverty line, $y_{i}$ is the relevant measure of welfare or the income of poor household from $i$ to $m$ which arrange in ascending order, $z$ is the poverty line income and $\alpha$ is a poverty aversion parameter. When $\alpha=0$, the resulting measure is the headcount index which provides an estimate of the proportion of households living in poverty. When $\alpha=1$, the FGT index results in the poverty gap index which provides a measure of the depth 
of poverty, that is the amount by which an average poor family is below the poverty line. The squared poverty gap index, which is sensitive to the extent of inequality among the poor, results when $\alpha=2$. In addition to these three measures, which are provided by default, the user may specify any non-negative value of alpha.

\section{Results and Discussions}

\subsection{Characteristics of Surveyed Peasants}

Table 2 illustrates some socio-demographic variables of peasants with respect to the surveyed districts. The average and percentages of these variables are also presented. It indicates that the average age of the improved mangrove rice and salt marsh producers was higher than other respondents. This confirms findings from Mignouna et al. (2011), who indicated that the older the household head, the greater the chances of adopting the improved technology in Western Kenya. Adoption of improved agricultural technologies has become a critical avenue for increasing productivity in developing countries, but is subject to serious limitations. The overall education level of surveyed peasants remains low, with an average of three years of schooling. However, it is important to note that the mean education level (Table 2) of traditional mangrove rice farmers is above the average of the overall sample. This can be explained through the presence of highly educated farmers who previously were working in SAKOBA (Note 2) shrimp farm. After the closure of this industrial farm, these highly educated persons went for the mangrove rice farming. In terms of family size, the sample size indicated an average of 11 members. The sample shows that gender represents $79 \%$ and $21 \%$ for male and female respectively. The traditional salt production (TSP/GS) shows that $76.7 \%$ of females involve in salt extraction. This significant involvement of women in traditional salt production was also reported by Serbin (2000), who stated that women represent $80 \%$ of salt producers in the Maritime Guinea region so called Guinean coastal zone. Once women are released from agricultural activities that last three to five months a year, they moved to the campsite of salt extraction where they extract salt which demands physical strength, thus compromising the health. The marital status was $99 \%$ married and $1 \%$ as single. Table 2 shows a higher migration among salt marsh producers representing $68 \%$. This significant number of migrant salt producers is not surprising since salt extraction is only limited to the Guinean coastal belt. Balde and Liagre (2008) suggested that an estimate of migrant traditional salt producers is important. The overall sample represents $69 \%$ and $31 \%$ of native and migrant farmers respectively.

Table 2. Socio-demographic profile of respondents

\begin{tabular}{lllllll}
\hline & \multicolumn{2}{c}{ Balessourou } & Taboria & \multicolumn{2}{l}{ Makinsi } & \multicolumn{2}{l}{ Bentya } & \multirow{2}{*}{ Overall } \\
\cline { 2 - 6 } & TSP/GS & SM & WE & TMR & IMR & \\
\hline Age (years) & $41.3(11.9)$ & $48.7(6.96)$ & $45.8(6.7)$ & $44.4(10.7)$ & $49.9(10.3)$ & $45.6(10.6)$ \\
Education level (years) & $2.4(3.2)$ & $2.7(2.9)$ & $3.9(3.8)$ & $5.1(5.5)$ & $2.9(3.8)$ & $3.3(4.1)$ \\
$\begin{array}{l}\text { Family size (persons) } \\
\text { Gender (dummy) }\end{array}$ & $9.9(3.5)$ & $12.5(4.1)$ & $11.6(4.2)$ & $10(5.2)$ & $11.3(3.9)$ & $10.9(4.3)$ \\
1=male (\%) & & & & & & \\
2=female (\%) & $23.3(0.06)$ & $100(0)$ & $95.0(0.1)$ & $100(0)$ & $100(0)$ & $78.6(0.03)$ \\
Marital status (dummy) & $76.7(0.06)$ & 0 & $5.0(0.1)$ & 0 & 0 & $21.4(0.03)$ \\
1=married (\%) & $100(0)$ & $100(0)$ & $100(0)$ & $94.0(0.03)$ & $100(0)$ & $98.6(0.01)$ \\
2=single (\%) & 0 & 0 & 0 & $6.0(0.03)$ & 0 & $1.4(0.01)$ \\
$\begin{array}{l}\text { Origin (dummy) } \\
\text { 1=native (\%) }\end{array}$ & $75(0.06)$ & $32.5(0.08)$ & $75(0.1)$ & $82(0.1)$ & $76.0(0.1)$ & $69.1(0.03)$ \\
2=migration (\%) & $25(0.06)$ & $67.5(0.08)$ & $25(0.1)$ & $18(0.1)$ & $24.0(0.1)$ & $30.9(0.03)$ \\
\hline
\end{tabular}

Values in parentheses are standard errors. IMR $=$ improved mangrove rice; TMR $=$ traditional mangrove rice; $\mathrm{WE}=$ wood extractors; $\mathrm{SM}=$ salt mash producers; $\mathrm{TSP} / \mathrm{GS}=$ traditional salt producers/Guinean saline. 


\subsection{Situation of Income Sources in Koba}

Table 3. Contribution to total income from different income sources

\begin{tabular}{|c|c|c|c|c|c|c|}
\hline \multirow[b]{4}{*}{ Respondents } & \multicolumn{5}{|c|}{ Districts } & \multirow{4}{*}{$\begin{array}{l}\text { Overall districts } \\
- \\
220\end{array}$} \\
\hline & \multicolumn{2}{|l|}{ Balessourou } & \multirow{2}{*}{$\begin{array}{l}\text { Taboria } \\
\text { WE }\end{array}$} & \multirow{2}{*}{$\begin{array}{l}\text { Makinsi } \\
\text { TMR }\end{array}$} & \multirow{2}{*}{$\begin{array}{l}\text { Bentya } \\
\text { IMR }\end{array}$} & \\
\hline & TSP/GS & SM & & & & \\
\hline & $60(27.3)$ & $40(18.2)$ & $20(9.1)$ & $50(22.7)$ & $50(22.7)$ & \\
\hline 1. Mangrove rice production & 0 & 934517 & & 1066391 & 2213909 & $4214817(26.10)$ \\
\hline 2. Lowland rice production & 0 & 0 & 0 & 88641 & 71064 & $159705(0.99)$ \\
\hline 3. Vegetables production & 0 & 0 & 0 & 167652 & 295391 & $463043(2.87)$ \\
\hline 4. Perennial crop prod. & 0 & 0 & 0 & 120208 & 54982 & $175190(1.08)$ \\
\hline 5. Seasonal crop prod. & 0 & 0 & 0 & 192714 & 157839 & $350553(2.17)$ \\
\hline 6. Salt production & 2634079 & 5417060 & 0 & 0 & 0 & $8051139(49.85)$ \\
\hline 7. Wood extraction & 0 & 0 & 763205 & 0 & 0 & $763205(4.73)$ \\
\hline 8. Non-farm income & 103003 & 56299 & 93642 & 428852 & 425270 & $1107066(6.85)$ \\
\hline 9. Remittance & 34864 & 33854 & 23452 & 24888 & 42923 & $159981(0.99)$ \\
\hline 10. Livestock & 0 & 13739 & 54573 & 256472 & 380212 & $704996(4.37)$ \\
\hline Overall income per district (GNF) & $2771946(17)$ & $6455469(40)$ & $934872(6)$ & $2345818(15)$ & $3641590(23)$ & 16149915 \\
\hline
\end{tabular}

IMR $=$ improved mangrove rice; TMR $=$ traditional mangrove rice; $\mathrm{WE}=$ wood extractors; $\mathrm{SM}=$ salt mash producers; TSP/GS = traditional salt producers/Guinean saline. GNF $=$ Guinean Franc. Values in parentheses are percentages.

Table 3 presents different income sources in respect to each district. A significant proportion (40\%) of average per capita income of salt marsh (SM) producers was derived from improved salt production technique in the district of Balessourou. The next significant proportion (23\%) of average per capita income of mangrove rice producers was also derived from improved mangrove rice production (IMR) in Bentya district. Therefore, traditional salt and mangrove rice producers are considered as the poorest because their overall incomes indicated $17 \%$ and $15 \%$ respectively (Table 3 ). These figures prove that poorer farmers get excluded from improved livelihood activities. This is very common in Africa and it is not different in Guinea. Based on the components of income, Table 3 revealed that the salt production income was significant, representing $50 \%$ followed by the income from the mangrove rice production (26\%). The contribution from non-farm income and wood extraction to total income represents $7 \%$ and $5 \%$ respectively. The agricultural income sources such as lowland rice, vegetables, perennial and seasonal crop production except mangrove rice production, contributes $7 \%$ to total income.

\subsection{Effects of Livelihood Activities on Income Inequality}

The estimates of the Gini decomposition analysis are presented in Table 4. The overall Gini coefficient (Table 4, column 3) of the total income of respondents is 0.3799 . This result is comparable to the Gini coefficients of 0.38 ; $0.38 ; 0.39 ; 0.39 ; 0.38$ and 0.39 that were derived respectively, for Cote d'Ivoire in 1995, Djibouti in 1996, Burkina Faso in 1995, Mauritania in 1995, Tanzania and Uganda in 1993 (Dollar \& Kraay, 2002). A Gini coefficient of 0.40 was also derived for Guinea (Dollar \& Kraay, 2002) which was a higher inequality compared to the Gini coefficient 0.38 (Table 4). Therefore, our Gini coefficient also presented higher inequality than Gini coefficients reported by IMF (2013), in poverty reduction strategy paper (PRSP) in Guinea in 2007 (0.31) and $2012(0.32)$. 
Table 4. Gini Decomposition by income source

\begin{tabular}{|c|c|c|c|c|c|c|}
\hline Income source & $\begin{array}{l}\text { Share in } \\
\text { total } \\
\text { income } \\
\text { (Sk) }\end{array}$ & $\begin{array}{l}\text { Gini } \\
\text { coefficient } \\
\text { for income } \\
\text { source (Gk) }\end{array}$ & $\begin{array}{l}\text { Gini } \\
\text { correlation } \\
\text { with total } \\
\text { income } \\
\text { rankings } \\
(\mathrm{Rk})\end{array}$ & $\begin{array}{l}\text { Absolute } \\
\text { contribution } \\
\text { to Gini Coeff. } \\
\text { of total } \\
\text { income } \\
\left(\mathbf{S k}^{*} \mathbf{G k} * \mathbf{R k}\right)\end{array}$ & $\begin{array}{l}\text { Share in } \\
\text { total } \\
\text { income } \\
\text { inequality }\end{array}$ & $\begin{array}{l}\text { Percentage } \\
\text { change in } \\
\text { overall Gini }\end{array}$ \\
\hline 1. Salt production & 0.5046 & 0.7011 & 0.7590 & 0.2685 & 0.7068 & 0.2022 \\
\hline 2. Non-farm income & 0.0714 & 0.7443 & 0.2464 & 0.0131 & 0.0345 & -0.0369 \\
\hline 3. Remittance & 0.0098 & 0.5975 & 0.0668 & 0.0004 & 0.0010 & -0.0088 \\
\hline 4. Livestock & 0.0451 & 0.7989 & 0.2493 & 0.0090 & 0.0236 & -0.0214 \\
\hline 5. Wood extraction & 0.0206 & 0.9270 & -0.7714 & -0.0147 & -0.0387 & -0.0592 \\
\hline 6. Mangrove rice production & 0.2712 & 0.5903 & 0.4703 & 0.0753 & 0.1982 & -0.0730 \\
\hline 7. Lowland rice production & 0.0108 & 0.9409 & 0.0261 & 0.0003 & 0.0007 & -0.0101 \\
\hline 8. Vegetables production & 0.0312 & 0.9658 & 0.6959 & 0.0210 & 0.0552 & 0.0240 \\
\hline 9. Seasonal crop prod. & 0.0236 & 0.8726 & 0.2397 & 0.0049 & 0.0130 & -0.0106 \\
\hline 10. Perennial crop & 0.0118 & 0.9114 & 0.2008 & 0.0022 & 0.0057 & -0.0061 \\
\hline Total income & & 0.3799 & & & & \\
\hline
\end{tabular}

The share of total income $\left(\mathrm{S}_{\mathrm{k}}\right)$ (Table 4) indicates the contribution of particular income sources to the overall income. Hence, Table 4 shows that salt production contributes to $50 \%$ or half of the total income, while the income from the mangrove rice production contributes $27 \%$. These figures confirm results relative to the contribution to the total income from different income sources as earlier discussed as per Table 3. The contribution to the total income from non-farm income and livestock represent $7 \%$ and $5 \%$ respectively. The overall Gini coefficient of 0.3799 (Table 4) represents the difference in incomes of households. Since the mean value of the total income of the sample is $16149915 \mathrm{GNF}$ (Table 3), the expected difference in the incomes of randomly selected households is $37.99 \%$ of the mean income of $16149915 \mathrm{GNF}$, or $6135353 \mathrm{GNF}$. This result of expected difference is lower than the one (46.7\%) found by Omilola, (2009) in Nigeria. In our results and when considering the expected difference $(37.99 \%$ of mean income), salt production income, mangrove rice income, non-farm income and wood extraction income (Table 3), their corresponding values become 3058628 GNF; 1601209 GNF; 420574 GNF and 289942 GNF respectively.

The third column (Table 4) represents the Gini coefficient $\left(\mathrm{G}_{\mathrm{k}}\right)$, which indicates equity in income distribution from each source of income. The Gk from different sources of income as a proportion of total Gk gives the contribution of each source of income to total inequality. For salt production income, the Gini coefficient dropped by $32.12 \%$ (from 0.7011 to 0.3799 ). Despite the highest contribution of salt production to total income, it is unequally distributed as indicated by the value of $\mathrm{G}_{\mathrm{k}}(0.7011)$. Generally, the distribution of income by different income sources shows a high inequality ranging from 0.59 to 0.97 much higher than the overall Gini coefficient of 0.38 . The share in total income inequality (Table 4, column 6 ) indicates that salt production was the most important contributor to income inequality ( $71 \%$ contribution). This inequality in salt production can be explained through the fact that when a new technology is introduced only peasants being organized into a group enjoy the benefits, whereas the poorer (non-organized peasants) get excluded which is a dilemma in Guinean rural areas. For example, among salt producers, only SM producers (93\%) belonging to an organized group, were found to receive tarpaulins (canvas or plastic sheets). These tarpaulins were provided by NGOs (e.g. La Charente Maritime) on a credit refundable basis after the salt harvesting. With respect to overseas training, only leaders from SM producers were offered this opportunity. 
Table 5. Bootstrap statistics

\begin{tabular}{|c|c|c|c|c|c|c|c|}
\hline \multirow{2}{*}{\begin{tabular}{|l|} 
Variable \\
Salt production
\end{tabular}} & \multirow{2}{*}{$\begin{array}{l}\text { Reps } \\
50\end{array}$} & \multirow{2}{*}{$\begin{array}{l}\text { Observed } \\
0.2022\end{array}$} & \multirow{2}{*}{$\begin{array}{l}\text { Bias } \\
-0.0036\end{array}$} & \multirow{2}{*}{$\begin{array}{l}\text { Std. Err. } \\
0.0385\end{array}$} & \multicolumn{2}{|c|}{ [95\% Conf. Interval] } & \multirow[b]{2}{*}{$(\mathrm{N})$} \\
\hline & & & & & 0.1249 & 0.2795 & \\
\hline & & & & & 0.1161 & 0.2539 & (P) \\
\hline & & & & & 0.1161 & 0.3085 & (BC) \\
\hline \multirow[t]{3}{*}{ Non-farm income } & 50 & -0.0369 & 0.0007 & 0.0106 & -0.0583 & -0.0156 & $(\mathrm{~N})$ \\
\hline & & & & & -0.0562 & -0.0108 & (P) \\
\hline & & & & & -0.0606 & -0.0108 & $(\mathrm{BC})$ \\
\hline \multirow[t]{3}{*}{ Remittance } & 50 & -0.0088 & -0.0001 & 0.0020 & -0.0128 & -0.0048 & $(\mathrm{~N})$ \\
\hline & & & & & -0.0127 & -0.0060 & (P) \\
\hline & & & & & -0.0139 & -0.0060 & (BC) \\
\hline \multirow[t]{3}{*}{ Livestock } & 50 & -0.0214 & 0.0005 & 0.0060 & -0.0335 & -0.0094 & $(\mathrm{~N})$ \\
\hline & & & & & -0.0312 & -0.0082 & (P) \\
\hline & & & & & -0.0333 & -0.0090 & $(\mathrm{BC})$ \\
\hline \multirow[t]{3}{*}{ Wood extraction } & 50 & -0.0592 & 0.0004 & 0.0125 & -0.0844 & -0.0341 & $(\mathrm{~N})$ \\
\hline & & & & & -0.0898 & -0.0376 & (P) \\
\hline & & & & & -0.0951 & -0.0376 & $(\mathrm{BC})$ \\
\hline \multirow[t]{3}{*}{ Mangrove rice production } & 50 & -0.0730 & 0.0013 & 0.0235 & -0.1202 & -0.0257 & $(\mathrm{~N})$ \\
\hline & & & & & -0.1168 & -0.0234 & (P) \\
\hline & & & & & -0.1168 & -0.0234 & $(\mathrm{BC})$ \\
\hline \multirow[t]{3}{*}{ Lowland rice production } & 50 & -0.0101 & -0.0002 & 0.0031 & -0.0162 & -0.0039 & $(\mathrm{~N})$ \\
\hline & & & & & -0.0145 & -0.0043 & (P) \\
\hline & & & & & -0.0145 & -0.0032 & $(\mathrm{BC})$ \\
\hline \multirow[t]{3}{*}{ Vegetables production } & 50 & 0.0240 & 0.0003 & 0.0148 & -0.0058 & 0.0538 & $(\mathrm{~N})$ \\
\hline & & & & & 0.0015 & 0.0529 & (P) \\
\hline & & & & & 0.0044 & 0.0564 & $(\mathrm{BC})$ \\
\hline \multirow[t]{3}{*}{ Seasonal crops production } & 50 & -0.0106 & 0.0005 & 0.0056 & -0.0220 & 0.0007 & $(\mathrm{~N})$ \\
\hline & & & & & -0.0208 & 0.0002 & (P) \\
\hline & & & & & -0.0247 & -0.0001 & $(\mathrm{BC})$ \\
\hline \multirow[t]{3}{*}{ Perennial crops production } & 50 & -0.0061 & 0.0002 & 0.0042 & -0.0145 & 0.0023 & $(\mathrm{~N})$ \\
\hline & & & & & -0.0143 & 0.0007 & $(\mathrm{P})$ \\
\hline & & & & & -0.0151 & 0.0007 & $(\mathrm{BC})$ \\
\hline
\end{tabular}

$\mathrm{N}=$ normal; $\mathrm{P}=$ percentile; $\mathrm{BC}=$ bias-corrected.

Mangrove rice production was the second most important contributor ( $20 \%$ contribution) to income disparity. This uneven distribution arose due to the mangrove rice farming types (improved and traditional). Furthermore, the difference related to farm size, inputs (type of seed varieties, fertilizer, agrochemical, labors, etc.) usage and output (productivity levels). Wood extraction was the only source of income contributing to income equality (Table 4). This can be attributed to the easy access to the mangrove forest resources in Kito and Keregnon Islands. Based on the field investigation, wood loggers stated that "there were no worries of replenishment because there is a quick regeneration of almost $98 \%$ of logged mangrove areas". Wood loggers revealed that this regeneration is accelerated thanks to the significant presence of marshy areas. The regeneration of mangroves and the remoteness of these islands from the main inland of Koba probably indicate the reason why all interviewed wood loggers mentioned that there is no ban on extraction from mangrove forest in the above mentioned islands. However, the ban of mangrove logging was imposed in the Balessourou district (located in the main inland of Koba) where salt production is conducted.

The effect on income inequality when there is a small change in a particular source of income can be observed in the last column. The estimates showed that a $1 \%$ increase in salt production income and vegetable production will increase the overall inequality by 20.22 and $2.4 \%$ respectively. However, a $1 \%$ increase in mangrove rice production, assuming other sources of income are constant, will reduce the overall inequality by $7.3 \%$. Similarly, the estimates indicated that $1 \%$ increase in non-farm income, remittance, livestock, wood extraction, lowland rice production, seasonal and perennial crop production, assuming other sources of income are constant, will reduce the overall disparity by $3.7 \% ; 0.9 \% ; 2.1 \% ; 6 \% ; 1 \% ; 1 \%$ and $0.6 \%$ respectively. 
The role of non-farm income on income inequality is reported by many researchers (De Janvry et al., 2005; Elbers \& Lanjouw, 2001). Idowu et al. (2011); Buchenrieder (2003); Knerr and Winnicki (2003) reported that non-farm rural employment can reduce poverty by generating alternative income sources and it can stimulate agricultural growth and mitigate rural to urban migration and the findings of De Janvry et al. (2005); Zvyagintsev et al. (2008) too supported this outcome. The Gini decomposition analysis allows the estimation of bootstrapped standard errors and confidence intervals. To guarantee reproducibility of the results of the Gini decomposition analysis (Table 4), bootstrap statistics were produced as shown in Table 5.

\subsection{Effects of Livelihood Activities on Poverty Reduction}

Both Table 6 and Table 7 show three different poverty measures by using FGT (Foster-Greer-Thorbecke) index. Firstly, the poverty headcount index (P0), set at 3217305 Guinean Franc (GNF) per person per year, indicating the poverty line in Guinea as of 2012 (INS, 2012). Next, the depth of poverty represents the amount by which the average per capita income of the poor falls short of the poverty line. This poverty measure reports the poverty gap index (P1), which is measured in percentage terms how far the average income of the poor falls short of the poverty line. For instance, a poverty gap of $10 \%$ means that the average poor person's income is $90 \%$ of the poverty line income. The third poverty measure is the squared poverty gap index (P2), indicates the severity of poverty. This squared poverty gap index possesses useful analytical properties, because it is sensitive to changes in distribution among the poor.

Table 6. Effect of salt and mangrove rice production incomes on poverty reduction

\begin{tabular}{|c|c|c|c|c|c|c|c|}
\hline \multirow{2}{*}{ Livelihood activities } & \multicolumn{3}{|c|}{ PLI $/ \alpha$} & \multirow{2}{*}{ Livelihood activities } & \multicolumn{3}{|c|}{ PLI/a } \\
\hline & $\mathrm{P} 0$ & $\mathrm{P} 1$ & $\mathrm{P} 2$ & & $\mathrm{P} 0$ & $\mathrm{P} 1$ & $\mathrm{P} 2$ \\
\hline 1.Salt production (SP) & 0.7409 & 0.6423 & 0.6051 & 1.Mangrove rice (MRP) & 0.9682 & 0.7232 & 0.6109 \\
\hline 2.SP+MRP & 0.7 & 0.4162 & 0.3021 & 2.MRP+SP & 0.7 & 0.4162 & 0.3021 \\
\hline 3.SP+OAI & 0.7273 & 0.5715 & 0.4966 & 3.MRP+OAI & 0.9318 & 0.6757 & 0.5661 \\
\hline 4.SP+NFI & 0.7318 & 0.574 & 0.4971 & 4.MRP+NFI & 0.9363 & 0.6613 & 0.5438 \\
\hline 5.SP+RE & 0.7409 & 0.6347 & 0.5923 & 5.MRP+RE & 0.9682 & 0.713 & 0.5965 \\
\hline 6.SP+L & 0.7409 & 0.5958 & 0.5249 & 6.MRP+ L & 0.9409 & 0.6869 & 0.5796 \\
\hline$[[2-1] / 1] * 10^{2}(\%)$ & -5.52 & -35.20 & -50.07 & {$[[2-1] / 1]^{*} 10^{2}(\%)$} & -27.70 & -42.45 & -50.55 \\
\hline$[[3-1] / 1] * 10^{2}(\%)$ & -1.84 & -11.02 & -17.93 & {$[[3-1] / 1]^{*} 10^{2}(\%)$} & -3.76 & -6.57 & -7.33 \\
\hline$[[4-1] / 1] * 10^{2}(\%)$ & -1.23 & -10.63 & -17.85 & {$[[4-1] / 1] * 10^{2}(\%)$} & -3.29 & -8.56 & -10.98 \\
\hline$[[5-1] / 1] * 10^{2}(\%)$ & 0 & -1.18 & -2.12 & {$[[5-1] / 1] * 10^{2}(\%)$} & 0 & -1.41 & -2.36 \\
\hline$[[6-1] / 1] * 10^{2}(\%)$ & 0 & -7.24 & -13.25 & {$[[6-1] / 1] * 10^{2}(\%)$} & -2.82 & -5.02 & -5.12 \\
\hline
\end{tabular}

$\mathrm{PLI}=$ poverty line index; $\mathrm{P} 0=$ poverty headcount index; $\mathrm{P} 1=$ poverty gap index; $\mathrm{P} 2=$ squared poverty gap index.

In order to determine the effect of salt production and mangrove rice production on poverty reduction, these two economic activities were associated with the other activities (Table 6). All the poverty measures (P0, P1 and P2) in respect to each combination show that the incorporation of salt production (SP) and mangrove rice production (MRP) into other activities could reduce the level, depth and severity of poverty in the study area. The size of the poverty reduction depends very much on how poverty is measured. Table 6 shows that when poverty is measured in terms of the headcount measure by associating the mangrove rice to salt production income, level of poverty is reduced by $5.52 \%$. Therefore, poverty is reduced much more when it measured by the depth and severity of poverty, such as the poverty gap and squared poverty gap.

Hence, the squared poverty gap measure indicates that inclusion of mangrove rice production (MRP) and other agricultural income (OAI) reduce poverty by $50 \%$ and $18 \%$ respectively. According to poverty headcount measure (Table 6, column 6); coupling each of the following income sources (salt production (SP), other agricultural income (OAI), non-farm income (NFI) and livestock (L) to mangrove rice production, the poverty level is reduced by $27.7 \%, 3.76 \%, 3.29 \%$ and $2.82 \%$ respectively. Table 6 shows that in respect to the headcount measure, the inclusion of remittance and animal rearing to the salt production income does not make any effect on the poverty reduction. Similarly, the inclusion of remittance (RE) to income from mangrove rice production does not produce any effect on the poverty reduction. 
Table 7. Effect of wood extraction income on Poverty reduction

\begin{tabular}{llll}
\hline \multirow{2}{*}{ Livelihood activities } & \multicolumn{3}{c}{ PLI/ $\boldsymbol{~}$} \\
\cline { 2 - 4 } & $\mathrm{P} 0$ & $\mathrm{P} 1$ & $\mathrm{P} 2$ \\
\hline $\mathbf{1 . W o o d}$ extraction $(\mathbf{W E})$ & 1 & 0.9784 & 0.9627 \\
$\mathbf{2 . W E}+\mathbf{N F I}$ & 0.9955 & 0.9059 & 0.8418 \\
$\mathbf{3 . W E}+\mathbf{R E}$ & 1 & 0.9681 & 0.9425 \\
$\mathbf{4 . W E}+\mathbf{L}$ & 1 & 0.9311 & 0.8819 \\
\hline$[[\mathbf{2}-\mathbf{1}] / \mathbf{1}] * \mathbf{1 0}^{\mathbf{2}}$ & -0.45 & -7.41 & -12.56 \\
{$[[\mathbf{3}-\mathbf{1}] / \mathbf{1}] * \mathbf{1 0}^{\mathbf{2}}$} & 0 & -1.05 & -2.10 \\
{$[[\mathbf{4 - 1}] / \mathbf{1}] * \mathbf{1 0}^{\mathbf{2}}$} & 0 & -4.83 & -8.39 \\
\hline
\end{tabular}

$\mathrm{PLI}=$ poverty line index; $\mathrm{P} 0=$ poverty headcount index; $\mathrm{P} 1=$ poverty gap index; $\mathrm{P} 2=$ =squared poverty gap index.

In Table 6, the three poverty measures (P0, $\mathrm{P} 1$ and $\mathrm{P} 2$ ) show that the extent of poverty reduction varies with respect to the type of activity integrated into the salt and mangrove rice production. For example, when mangrove rice production is incorporated in salt production income, the effect on the poverty reduction is significant. The reduction in headcount ratio, depth of poverty and squared gap index are $5.52 \%, 35.20 \%$ and $50.07 \%$ respectively. The reduction with respect to these three measures is $27.7 \%, 42.45 \%$ and $50.55 \%$ respectively, when the salt production and mangrove rice income are combined.

Table 7 shows the effect of wood extraction income when incorporated into other income sources, except income from mangrove rice and salt production. These two activities were not associated with wood extraction. Table 7 indicates that when the wood extraction income is incorporated into non-farm income, the effect on poverty reduction is high. The reduction in headcount, depth of poverty and squared gap indices are $0.45 \%, 7.41 \%$ and $12.56 \%$ respectively. However, based on the depth of poverty and squared gap ratio, the effect on poverty reduction is low when wood extraction income is included to remittance and livestock. There is no effect when it is estimated based on headcount ratio or poverty line (Table 7).

Reardon \& Taylor, (1996), used Gini and Foster-Thorbecke-Greer decompositions of income inequality and poverty in the Sahelian zone of Burkina Faso before and after the severe drought of 1984. They revealed that in 1983, the poverty level was higher in the Sudanian zone (0.12, compared with 0.02 in the Sahelian zone and 0.01 in the Guinean zone). Our results relative to poverty indices (Tables $6 \& 7$ ) revealed a higher poverty level compared to their findings. Reardon and Taylor (1996) stated that understanding the links between income inequality and poverty is particularly important in Africa, where poverty is widespread and where, given low per-capita incomes, the poverty consequences of changes in the income distribution are likely to be significant.

\subsection{Household Assets, Access to Housing and Energy Consumption}

In order to justify the inequality among surveyed peasants, variables related to household assets, access to housing and energy consumption were examined. Among household assets, items such as refrigerator, TV, bicycle, bike, car, radio, mobile phone, stove charcoal and rocket stove and tripod were considered. Access to housing considered the state of the wall and the floor. With respect to access to energy consumption, respondents rely on charcoal, kerosene, gas/batteries, fuel wood from mangrove and upland forest. Rakodi (1999) reported that improved access to physical or produced capital (basic infrastructure and the production equipment and means which enable people to pursue their livelihoods) is an essential element of strategies to reduce household poverty. 
Table 8. Household assets and Access to housing and energy sources in the household

\begin{tabular}{|c|c|c|c|c|c|c|c|c|c|c|}
\hline \multicolumn{4}{|c|}{ Variables } & \multirow{2}{*}{$\begin{array}{r}\begin{array}{r}\text { WE } \\
(\%)\end{array} \\
9.1\end{array}$} & \multirow{2}{*}{$\begin{array}{l}\begin{array}{l}\text { TSP/GS } \\
(\%)\end{array} \\
1.8\end{array}$} & \multirow{2}{*}{$\begin{array}{c}\begin{array}{l}\text { SM } \\
(\%)\end{array} \\
18.2\end{array}$} & \multirow{2}{*}{$\begin{array}{c}\begin{array}{l}\text { TMR } \\
(\%)\end{array} \\
22.7\end{array}$} & \multirow{2}{*}{$\begin{array}{c}\begin{array}{l}\text { IMR } \\
(\%)\end{array} \\
22.7\end{array}$} & \multirow{2}{*}{$\begin{array}{c}\begin{array}{l}\text { Total } \\
(\%)\end{array} \\
74.5\end{array}$} & \multirow{2}{*}{$\begin{array}{l}\text { p-value } \\
0.000^{* * *}\end{array}$} \\
\hline Access to housing & Wall & Thatched & No & & & & & & & \\
\hline & & & Yes & 0 & 25.5 & 0 & 0 & 0 & 25.5 & \\
\hline & & Wooden & No & 9.1 & 5.5 & 18.2 & 22.7 & 22.7 & 78.2 & $0.000^{* * *}$ \\
\hline & & & Yes & 0 & 21.8 & 0 & 0 & 0 & 21.8 & \\
\hline & & Mud & No & 9.1 & 17.3 & 18.2 & 19.5 & 16.4 & 80.5 & $0.000^{* * *}$ \\
\hline & & & Yes & 0 & 10.0 & 0 & 3.2 & 6.4 & 19.5 & \\
\hline & & Brick $^{\odot}$ & No & 0 & 23.6 & 0 & 2.3 & 1.8 & 27.7 & $0.000^{* * *}$ \\
\hline & & & Yes & 9.1 & 3.6 & 18.2 & 20.5 & 20.9 & 72.3 & \\
\hline & Floor & soil & No & 3.2 & 1.8 & 16.4 & 12.7 & 14.5 & 48.6 & $0.000^{* * *}$ \\
\hline & & & Yes & 5.9 & 25.5 & 1.8 & 10.0 & 8.2 & 51.4 & \\
\hline & & cowpat & No & 9.1 & 24.5 & 18.2 & 20.0 & 20.9 & 92.7 & 0.133 \\
\hline & & & Yes & 0 & 2.7 & 0 & 2.7 & 1.8 & 7.3 & \\
\hline & & cement $^{\mathcal{O}}$ & No & 4.5 & 23.6 & 1.4 & 10.5 & 3.6 & 43.6 & $0.000^{* * *}$ \\
\hline & & & Yes & 4.5 & 3.6 & 16.8 & 12.3 & 19.1 & 56.4 & \\
\hline \multirow[t]{20}{*}{ Household assets } & \multirow{2}{*}{\multicolumn{2}{|c|}{ Refrigerator $^{\circ}$}} & No & 9.1 & 27.3 & 18.2 & 22.7 & 22.7 & 100 & $\mathrm{a}$ \\
\hline & & & Yes & 0 & 0 & 0 & 0 & 0 & 0 & \\
\hline & \multirow{2}{*}{\multicolumn{2}{|c|}{ Television $^{\odot}$}} & No & 9.1 & 26.4 & 17.7 & 21.4 & 20.9 & 95.5 & 0.531 \\
\hline & & & Yes & 0 & 0.9 & 0.5 & 1.4 & 1.8 & 4.5 & \\
\hline & \multirow{2}{*}{\multicolumn{2}{|c|}{ Bicycle }} & No & 5.9 & 8.6 & 2.7 & 12.7 & 8.6 & 38.6 & $0.000^{* * *}$ \\
\hline & & & Yes & 3.2 & 18.6 & 15.5 & 10.0 & 14.1 & 61.4 & \\
\hline & \multirow{2}{*}{\multicolumn{2}{|c|}{ Motorbike $^{(}$}} & No & 9.1 & 20.0 & 5.9 & 13.6 & 7.7 & 56.4 & $0.000^{* * *}$ \\
\hline & & & Yes & 0 & 7.3 & 12.3 & 9.1 & 15.0 & 43.6 & \\
\hline & \multirow{2}{*}{\multicolumn{2}{|c|}{$\mathrm{Car}^{\mathrm{C}}$}} & No & 9.1 & 25.5 & 15.0 & 22.7 & 22.7 & 95.0 & $0.001^{* * *}$ \\
\hline & & & Yes & 0 & 1.8 & 3.2 & 0 & 0 & 5.0 & \\
\hline & \multirow{2}{*}{\multicolumn{2}{|c|}{ Radio }} & No & 0.9 & 3.2 & 1.4 & 7.7 & 10.0 & 23.2 & $0.000^{* * *}$ \\
\hline & & & Yes & 8.2 & 24.1 & 16.8 & 15.0 & 12.7 & 76.8 & \\
\hline & \multirow{2}{*}{\multicolumn{2}{|c|}{ Mobile phone }} & No & 1.8 & 25.0 & 0.9 & 8.2 & 8.6 & 44.5 & $0.000^{* * *}$ \\
\hline & & & Yes & 7.3 & 2.3 & 17.3 & 14.5 & 14.1 & 55.5 & \\
\hline & \multirow{2}{*}{\multicolumn{2}{|c|}{ Stove $_{\text {charcoal }}{ }^{\odot}$}} & No & 9.1 & 12.3 & 11.4 & 11.8 & 22.7 & 67.3 & $0.000^{* * *}$ \\
\hline & & & Yes & 0 & 15.0 & 6.8 & 10.9 & 0 & 32.7 & \\
\hline & \multirow{2}{*}{\multicolumn{2}{|c|}{$\begin{array}{l}\text { Rocket stove efficient } \\
\text { wood cooker }\end{array}$}} & No & 3.6 & 23.6 & 4.5 & 14.1 & 6.8 & 52.7 & $0.000^{* * *}$ \\
\hline & & & Yes & 5.5 & 3.6 & 13.6 & 8.6 & 15.9 & 47.3 & \\
\hline & \multirow{2}{*}{\multicolumn{2}{|c|}{ Tripod }} & No & 2.3 & 4.5 & 13.2 & 11.4 & 15.9 & 47.3 & $0.000^{* * *}$ \\
\hline & & & Yes & 6.8 & 22.7 & 5.0 & 11.4 & 6.8 & 52.7 & \\
\hline \multirow{12}{*}{$\begin{array}{l}\text { Access to energy } \\
\text { consumption }\end{array}$} & 1. & wood from & No & 0 & 25.9 & 18.2 & 4.1 & 11.8 & 60.0 & $0.000^{* * *}$ \\
\hline & mang1 & forest & Yes & 9.1 & 1.4 & 0 & 18.6 & 10.9 & 40.0 & \\
\hline & 2. & wood from & No & 0 & 0 & 0 & 8.6 & 0.9 & 9.5 & $0.000^{* * *}$ \\
\hline & uplan & & Yes & 9.1 & 27.3 & 18.2 & 14.1 & 21.8 & 90.5 & \\
\hline & 3. Chr & & No & 7.7 & 5.9 & 10.9 & 9.1 & 22.7 & 56.4 & $0.000^{* * *}$ \\
\hline & & & Yes & 1.4 & 21.4 & 7.3 & 13.6 & 0 & 43.6 & \\
\hline & 4. Ele & city $^{\mathcal{O}}$ & No & 9.1 & 27.3 & 18.2 & 22.7 & 22.7 & 100 & $\mathrm{a}$ \\
\hline & & & Yes & 0 & 0 & 0 & 0 & 0 & 0 & \\
\hline & 5. Ker & & No & 9.1 & 27.3 & 18.2 & 21.8 & 10.0 & 86.4 & $0.000^{* * *}$ \\
\hline & & & Yes & 0 & 0 & 0 & 0.9 & 12.7 & 13.6 & \\
\hline & 6. Gas & tteries & No & 5.5 & 27.3 & 12.3 & 20.5 & 5.0 & 70.5 & $0.000^{* * *}$ \\
\hline & & & Yes & 3.6 & 0 & 5.9 & 2.3 & 17.7 & 29.5 & \\
\hline
\end{tabular}

(C) = convenient household resources mostly owned by wealthiest peasants; a $=$ no statistics are computed because the variable is a constant. $* * *=$ statistically significant at $1 \%$ level. 
Ndambiri et al. (2012) stated that series of livelihood outcomes had emanated from the economic ways of life of farm households in Kenya. These outcomes lead to increased financial ability of the households to: (1) acquire more land for farming, (2) starting businesses, (3) hire more land for cultivation, (4) put up toilets, (5) roof houses with iron sheets, (6) put up stone walls in their houses, (7) pay cooperative fees and (8) improve floor material of their houses. Table 8 indicates that access to housing relative to wall and floor indicated a significant difference among respondents. Access to thatched and wooden walls was only found in campsites of the traditional salt producers. Despite the significant availability of wall with bricks $(72.3 \%)$ more than $50 \%$ of walls were without cement layers. The brick walls with cemented layers represent a sign of decent housing. However, thatched, muddy and wooden walls indicate a sign of household living in poverty. In addition, floor with soil and cowpat is an indication of peasants living in poverty. The cemented floor $(56.4 \%)$ is an indication of better off peasants.

In Guinea, IMF, (2013) reported that in terms of inequity of access to decent housing, the percentage of individuals who have shelters with permanent walls grew nearly 9\% in the countryside between 2007 (22.6\%) and $2012(31.5 \%)$. There are also problems of access to property ownership. Of $77.4 \%$ homeowners, about $32 \%$ own their houses in urban areas. The rate of house rent remains high, in Conakry (about 54\%) as well as in other cities in the country (about 55\%). Access to home ownership is hampered by various factors (Note 3 ).

Household asset ownership revealed the difference among respondents, indicating that most of them are poor since nobody owned a refrigerator. In addition, only 5\% reported having a car. Respondents using tripod (52.7\%) are vulnerable to poverty. Vulnerability to poverty can first be defined as a probabilistic concept: it is the risk of falling into poverty when one's income or consumption falls below a predefined poverty line. This calls for a quantitative approach to vulnerability that implies estimating a probability as well as selecting a poverty line (Note 4) (Echevin, 2013). Echevin (2013) measured the vulnerability to asset-poverty in Sub-Saharan Africa using an asset-based index. Among household assets, Echevin (2013), considered liquid assets such as: radio, television, refrigerator, bicycle and car. He also considered more durable assets such as housing. This encompassed tap water, surface water, flush toilet, no toilets, electricity and finished floor. Those households owning television, refrigerator, or car are among the wealthiest, whereas those declaring only a radio or a bicycle are among the poorest. In addition, households with access to electricity; tap water and flush toilet are among the wealthiest (Echevin, 2013).

Access to energy consumption is also an important indicator for evaluating the level of poverty among surveyed peasants. Table 8 shows that electricity was not available for all peasants. Energy consumption comes mainly from firewood of upland forest (90.5\%), charcoal (43.6\%) and firewood of mangrove forest (40\%). These figures indicated that the majority of surveyed peasants rely on the natural resources. The natural resources on which the rural poor most depend may, because of their lack of access to private assets, be common pool resources (Rakodi, 1999).

IMF, 2013 reported that Guinean households barely use clean energy (gas and electricity) because of low income. Rather, they have access to wood and its by-products. More than $74 \%$ of households (ELEP, 2012) use firewood for cooking and more than one household in five (23.9\%) use charcoal. This, on the one hand, adds to the burden of women and girls, notably in rural areas, when they have to walk long distances to fetch wood for cooking. And, this situation leads to the degradation of resources, especially because of strong pressure from the poor population that depends on these resources (especially on the outskirts of Conakry), along with deforestation and deteriorating soil fertility, which could reduce agricultural productivity.

In terms of unequal access to electricity, the percentage of individuals benefitting from this source of lighting grew slightly in the countryside between 2007 (1.4\%) and 2012 (2.6\%). On the other hand, in urban areas, there has been a strong decline of access to electricity by 10.2\% between 2007 (65.7\%) and 2012 (55.5\%). In 2012, one out of five households at national level used electricity as an energy source for lighting, mainly in urban areas. In rural areas, the service was virtually unavailable. All regions, with the exception of Conakry, find it difficult to access this source of energy because the supply is weak, and poverty has worsened, especially in the towns.

\section{Conclusion and Recommendations}

This paper examines the effect of livelihood activities on the income inequality and poverty reduction based on a survey conducted in four districts (Balessourou, Taboria, Makinsi and Bentya) of Koba located in the Guinean coastal area. Income inequality is considered as one of the major contributing factors to poverty and food security in developing countries. Understanding the key sources of inequality in the coastal zone of Guinea could provide a framework for generating useful information for development policy on how policy makers could 
rectify or remedy the income inequality in order to bring about poverty reduction. With respect to the socio-demographic variables, the study indicated that surveyed peasants' level of education was low while they had large families. The study revealed that the proportion of income is higher in Balessourou and Bentya districts where improved salt and mangrove rice production are practiced respectively. Overall, salt production and mangrove rice cultivation contribute to the total household income by $50 \%$ and $26 \%$ respectively; followed by non-farm income and wood extraction by $7 \%$ and $5 \%$ respectively.

The Gini decomposition analysis revealed that increasing the income share of mangrove rice production, wood extraction and non-farm income could alleviate poverty and reduce income inequality among peasants in the study area. Although increasing the income share of salt production would not decrease inequality, it remains one of the most important sources of income and benefits more rich peasants. This implies that salt production has the potential for increasing inequality. Moreover, decomposition carried out on poverty index indicated that the extent of poverty reduction varies with respect to the type of combination of livelihood activities.

In this research, household assets, access to housing and household energy consumption confirm the poverty level and the income distribution inequality among surveyed peasants. Analysis of household capital assets and livelihood strategies needs to be both dynamic and differentiated (Rakodi, 1999). An advantage of capital assets is that it places the reality of domestic groups (generally conceptualized as households) at the centre of analysis and policy, without ignoring the contextual economic, political and social factors which determine their ability to construct sustainable livelihood strategies. It provides a more adequate multi-dimensional understanding of poverty, impoverishment and increased well-being than analysis of income or consumption alone. Rakodi (1999), also reported that there is some evidence of the beneficial impacts of policies for increasing the assets available to poor households and relieve constraints on their ability to cope with impoverishment or take advantage of opportunities to enhance their livelihood.

Findings from this research suggest that policy makers, interested in remedying income disparities and reducing poverty in the Guinean coastal area, need to pay more attention on technology transfer and extension services to improve mangrove rice production as it accounts for $27 \%$ of the share of total income. Furthermore, the relative marginal effect indicates that $1 \%$ increase in mangrove rice production will reduce poverty by $7.3 \%$. This implies that mangrove rice production exerts the highest impact on poverty reduction from among all the livelihood activities. The government could remedy the income inequality arising from salt production and reduce poverty by providing machineries and tools to poorer farmers to ensure their inclusion in the salt production. NGOs and other organizations should come forward to support the government financially, teach farmers about advanced techniques of salt production and give due recognition to producers. In addition, the government should provide subsidies and/or credits to poorer farmers for rectifying income inequality and alleviate poverty because salt production is capital intensive. Policy makers and different actors involved in the Guinean coastal area are requested to take further efforts to rectify income inequality and poverty alleviation through the provision of extension programs and credit services to rural areas until improved access to market opportunities created a demand for technology and inputs. This strategy could lead to the improved household assets, access to better housing and modern energy consumption. The latter one could play a significant role with respect to the sustainable management of natural resources including the mangrove and upland forests. These recommendations will pave the way to improve rural livelihoods and conserve natural resources and biodiversity.

\section{References}

Agbugba, I. K., \& Ajuruchukwu, O. (2013). Market Structure, Price Formation and Price Transmission for Wood Charcoal in Southeastern Nigeria. Journal of Agricultural Science, 5(10), 77-86. http://dx.doi.org/10.5539/jas.v5n10p77

Alderman, H., \& Paxson, C. H. (1992). Do the poor insure? A synthesis of the literature on risk and consumption in developing countries. Policy Research Working Paper, WPS 1008. Washington DC: The World Bank.

Alina, J. (2008). Decomposition of the Gini Index by Sources of Income. Int. Adv. Econ. Res., 14, 441-447.

Aryeetey, E., Owusu, G., \& Mensah, E. J. (2009). An analysis of poverty and regional inequalities in Ghana. Working Paper 27, Global Development Network, New Delhi.

Azam, M., \& Shariff, A. (2011). Income Inequality in Rural India: Decomposing the Gini by Income Sources. Economics Bulletin, 31(1), 739-748. 
Balde, B. S., Kobayashi, H., Matsumura, I., Nohmi, M., Esham, M., \& Tolno, E. (2013a). Present Status and Determinants of Mangrove Rice Production in Dubreka prefecture in Guinea. Japanese Journal of Farm Management, 51(3), 97-102.

Balde, B. S., Kobayashi, H., Nohmi, M., Ishida, A., Matsumura, I., Esham, M., \& Tolno, E. (2013b). Socio-Economic Analysis of small-scale salt production techniques in the coastal area of Guinea: An alternative for improving livelihood status and mangrove forest management. International Journal of Research in Engineering, IT and Social Science (IJREISS), 3(9), 1-23.

Balde, Y., \& Liagre, L. (2008). Evaluation des actions de l'association Univers-Sel de 2005 à 2007: Programme de développement durable de la production de mangrove en Guinée Maritime - Réhabilitation de la riziculture traditionnelle et production de sel. Synthèse du rapport final. Retrieved from http://f3e.asso.fr///IMG/pdf/Synthese_Univers-Sel_251_Ev_finale.pdf

Barber, C. (2008). Notes on Poverty and Inequality. Background Paper Written as a Contribution to the Development of: Green, D., From Poverty to Power: How Active Citizens and Effective States Can Change the World. Oxfam International, Oxford.

Bourguignon, F. (2004). The poverty-growth-inequality triangle. Indian Council for Research on International Economic Relations, Working Paper 125, New Delhi.

Buchenrieder, G. (2003). Overview of poverty impacts of and policy option for non-farm rural employment. In B T. W. Knerr (Ed.), Proceeding of the Minisymposium at the 25th International Conference of Agricultural Economists, Durban, South Africa, University of Hohenheim Stuttgart, pp.1-23.

De Janvry, A., Sadoulet, E., \& Zhu, N. (2005). The role of nonfarm incomes in reducing poverty and inequality in China. CUDARE working paper 1001, Berkeley: University of California.

Dollar, D., \& Kraay, A. (2002). Growth is good for the poor. Journal of Economic Growth, 7, 195-225. In E. Anderson \& A. McKay (Eds.), Why is inequality so high, but also so variable, in Sub-Saharan Africa? Preliminary Draft, August.

Echevin, D. (2013). Measuring Vulnerability to Asset-Poverty in Sub-Saharan Africa. World Development, 46, 211-222. http://dx.doi.org/10.1016/j.worlddev.2013.02.001

Elbers, C., \& Lanjouw, P. (2001). Intersectoral Transfer, Growth and Inequality in Rural Ecuador. World Development, $29(3), 481-496$.

Foster, J., Greer, J., \& Thorbecke, E. (1984). A class of decomposable poverty measures. Econometrica, 52, 761-765.

Fosu, A. (2011). Growth, inequality, and poverty reduction in developing countries: Recent global evidence. BWPI Working Paper 147, University of Manchester, Manchester.

Gini, C. (1912). Variabilità e mutabilità, in "Studi economico-giuridici della Facoltà di Giurisprudenza". Università di Cagliari.

Heshmati A. (2004). A Review of decomposition of income inequality. IZA Discussion Paper No. 1221. Retrieved from http://ftp.iza.org/dp1221.pdf

Idowu, A. O., Banwo, A., \& Akerele, E. O. (2011). Non-farm Activities and Poverty among Rural Farm Households in Yewa Division of Ogun State. J. Soc. Sci., 26(3), 217-224.

Imai, K. S., Gaiha, R., \& Thapa, G. (2010). Is the millennium development goal of poverty still achievable? Role of institutions, finance and openness. Oxford Development Studies, 38, 309-337.

IMF [International Monetary Fund]. (2013). Guinea: poverty reduction strategy paper PRS III (2013-2015). IMF country report No. 13/191.

ISN. (2012). Poverty and Inequality in Guinea from 1994 to 2012: Analysis from Household Surveys (Final Version) in French. National Statistical Institute. Retrieved from http:/www.stat-guinee.org/DSRP/PDF/ Pauvrete\%20Inegalite\%20Guinee_fVer2_\%2021\%2008\%20\%202012.pdf

Kanbur, R., \& Venables, A. J. (2003). Introduction. In R. Kanbur \& A. J. Venables (Eds.), Spatial Inequality and Development (pp. 1-10). WIDER, Helsinki.

Knerr, B., \& Winnicki, T. (2003). Keeping alive through nonfarm income: Facts and concepts in the region of Warminsko-Mazurski, Poland. In B. Knerr \& T. Winnicki (Eds.), Proceeding of the Mini-symposium at the 
25th International Conference of Agricultural Economists. Durban, South Africa, University of Hohenheim Stuttgart, pp. 80-98.

Lerman, R. I., \& Yitzhaki, S. (1985). Income inequality effects by income source: A new approach and applications to the United States. Review of Economics and Statistics, 67, 151-156

McKay, A., \& Aryeetey, E. (2007). Growth with poverty reduction, but increased spatial inequality: Ghana over the 1990. In S. Klasen, M. Grimm \& A. McKay (Eds.), Determinants of Pro-Poor Growth: Analytical Issues and Findings from Country Cases (pp. 57-80). Palgrave Macmillan, New York.

Mignouna, D. B., Manyong, V. M., Rusike, J., Mutabazi, K. D. S., \& Senkondo, E. M. (2011). Determinants of Adopting Imazapyr-Resistant Maize Technologies and its Impact on Household Income in Western Kenya. AgBioForum, 14(3), 158-163.

Mosse, D. (2010). A relational approach to durable poverty, inequality and power. Journal of Development Studies, 46, 1156-1178.

NAP [The National Academies Press]. (1996). Lost Crops of Africa: Volume I: Grains, "3 Fonio (Acha)." Washington, DC.

Ndambiri, H. K., Okello, J. J., Ng'ang'a, S. I., Ritho, C., Minyacha, S. O., Omboto, P. I., \& Kubowon, P. C. (2012). Income Distribution and Livelihood Analysis among Horticulture Farming Households in Nyeri District, Kenya. International Journal of Business and Social Science, 3(19), 61-69.

Okamoto, M. (2009). Decomposition of Gini and multivariate Gini indices. The Journal of Economic Inequality, $7(2), 153-177$.

Omilola, B. (2009). Rural Non-farm Income and Inequality in Nigeria. IFPRI [The International Food Policy Research Institute] Discussion Paper 00899.

Peters, M. M., \& Shapouri, S. (1997). Income inequality and food security. Economic Research Service/USDA. Retrieved from http://www.ers.usda.gov/Briefing/GlobalFoodSecurity/PDF/gfa9cIncomeInequalityandFood Security.pdf.

Pritchett, L., Suryahadi, A., \& Sumarto, S. (2000). Quantifying vulnerability to poverty: A proposed measure, applied to Indonesia. World Bank Social Monitoring and Early Response Unit.

Rakodi, C. (1999). A capital assets framework for analyzing household livelihood strategies: Implications for policy. Development policy review, 17(1999), 315-342.

Ravallion, M. (1997). Can high-inequality developing countries escape absolute poverty? Economic Letters, 56, 51-57.

Ravallion, M. (2001). Growth, inequality, and poverty: looking beyond averages. World Dev, 29(11), 1803-1815.

Reardon, T., \& Taylor, J. E. (1996). Agroclimatic Shock, Income Inequality, and Poverty:Evidence from Burkina Faso. World Development, 24(5), 901-914.

Rudie, I. (1995). The significance of eating, cooperation, support and reputation in Kelantan Malay households. World Development, 27(2), 415-422.

Sen, A. (1999). Choice, welfare and measurement. London, England: Harvard University Press.

Sen, A. K. (1976). Poverty: an ordinal approach to measurement. Econometrica, 44, 219-231.

Serbin, S. (2000). Productrices de Guinée maritime: le sel de la terre. Grain de sel. № 16. Novembre.

Shorrocks, A. F. (1982). Inequality decomposition by factor components. Econometrica, 50(1), 193-211.

Singh, K., \& Dey, M. M. (2010). Sources of family income and their effects on family income inequality: a study of fish farmers in Tripura, India. Food Sec., 2, 359-365. http://dx.doi.org/10.1007/s12571-010-0082-3

Stata Technical Bulletin (STB). (1999). A publication to promote communication among Stata users. STB-48

UNDP [United Nations Development Programme]. (1992). The importance of forestry statistics. Retrieved from http://www.atyponlin.com/CFA/doi/abs/-10.1505/ifor.8.1.4

World Bank. (2009). World Development Report 2009: Reshaping Economic Geography. World Bank, Washington, DC. 
Zvyagintsev, D., Shick, O., Serova, E., \& Lerman, Z. (2008). Diversification of rural incomes and non-farm rural employment: Evidence from Russia. Discussion Paper No. 3.08, Jerusalem: Department of Agricultural Economics and Management, Hebrew University.

\section{Notes}

Note 1. Fonio (Digitaria exilis and Digitaria iburua) is probably the oldest African cereal. For thousands of years West Africans have cultivated it across the dry savannas. Indeed, it was once their major food. Even though few other people have ever heard of it, this crop still remains important in areas scattered from Cape Verde to Lake Chad. In certain regions of Mali, Burkina Faso, Guinea, and Nigeria, for instance, it is either the staple or a major part of the diet. Each year West African farmers devoted about 300,000 hectares for cultivating fonio, and the crop supplies food to 3-4 million people (NAP, 1996). Fonio (Digitaria exilis) has been grown in West Africa for centuries. For a long time, it was of marginal importance as a cereal due to its small seeds, but is now the object of renewed interest as consumers begin to recognize its flavour and nutritional qualities. Research is under way with a view to mechanizing several processing stages, so as to increase fonio sales in the urban areas, where it is particularly popular.

Note 2. The $S A K O B A$ shrimp farm was established in 1995 and the production was shut down in 1999. This industrial farm built by the Guinean Government included 400 hectares of ponds with a processing plant and hatchery which did not produce more than 250 tons. Among the serious problems of poor management and the choice of an inadaptable site- production has never been operational to date. A large scale hatchery was located on the isolated island of Tamara, offshore of Conakry, while the farm was located over two hours by road up the coast of Guinea in the region of Koba. From its inception, the project was plagued by cost over-runs and poor management. These problems were compounded by logistical issues (proximity of the two integral facilities), and unmanageable technical problems (acid soil, and silted water on the farm).

Note 3. (i) the lack of a suitable financing mechanism, (ii) the inexistence of a Bank dedicated to housing (especially social) and the lack of credit channels specific to housing in classic banking and financial networks; (iii) weak support for a wide-scale do-it-yourself construction system; (iv) a high level of poverty that deprives a large segment of the population from access to housing; (v) the absence of public-private partnerships and the weak performance of the Guinean private sector in the development of real estate; (vi) women's lack of access to property ownership.

Note 4. An intuitive threshold is when the probability of being poor in the future exceeds $50 \%$; people should be considered vulnerable in this case since they are more likely to fall into poverty than not to be poor in the future (Pritchett et al., 2000).

\section{Copyrights}

Copyright for this article is retained by the author(s), with first publication rights granted to the journal.

This is an open-access article distributed under the terms and conditions of the Creative Commons Attribution license (http://creativecommons.org/licenses/by/3.0/). 